\title{
Faktor Determinan yang berhubungan dengan Kepuasan Kerja Perawat Pelaksana di RSUD Dr. Rasidin Padang
}

\author{
Erni Musmiler ${ }^{1}$, Yulastri Arif ${ }^{2}$, Wawan Wahyudi ${ }^{3}$ \\ ${ }^{1}$ Program Studi S-1 Keperawatan STIKes YPAK Padang \\ ${ }^{2,3}$ Fakultas Keperawatan, Universitas Andalas \\ Email : erni.musmiler@gmail.com
}

\begin{abstract}
Job satisfaction of nurses need serious attention because nurses care provider with the largest and longest time to patients. The achievement of hospitals BOR is low (26.20\%) that be caused the result of achievement of the performance of nurses are not optimal yet, this is caused to the dissatisfaction of nurses to hospitals management. The aim of this research is to find determinant factors that related to job satisfaction of nurses executive in RSUD dr. Rasidin Padang. This research is know deskriptive correlation with cross sectional to 72 executive nurses in RSUD dr. Rasidin. Instrument of the research is questionnaire. Univariate data analysis used frequency distribution, bivariate with chi square test, and multivariate used logistic regression test. The result of the research is $51.4 \%$ executive nurses state dissatisfaction in working. Chi-square test is obtained there is significant correlation between the incentive, promotion opportunity, and supervision with job satisfaction. There is not correlation between the leadership, and work environment condition with job satisfaction. The result of multivariate analysis is obtained variable incentive that is dominant factors related to job satisfaction of nurses. It is expected the stakeholders of hospital management to consider the burned and risk of work based on objective performance assesment, the setting of level system performance-based on achievement career. Running the monitoring system to nursing care is given by executive nurses, and immediately to do accreditation of hospital to improve the quality of hospital services.
\end{abstract}

Keywords: determinant faktor, job Satisfaction, nurses

\begin{abstract}
Abstrak
Kepuasan kerja perawat perlu mendapat perhatian serius karena perawat pemberi pelayanan dengan waktu terbanyak dan terlama pada pasien. Pencapaian BOR rumah sakit yang rendah $(26,20 \%)$ bisa disebabkan oleh hasil pencapaian kinerja perawat belum optimal, hal ini dapat disebabkan oleh ketidak puasan perawat terhadap manajemen rumah sakit. Tujuan penelitian untuk mengetahui faktor determinan yang berhubungan dengan kepuasan kerja perawat pelaksana. Penelitian ini deskripitif korelasi dengan pendekatan cross sectional pada 72 orang perawat pelaksana di RSUD dr. Rasidin. Pengumpulan data dengan kuesioner. Analisa data univariat menggunakan distribusi frekuensi, bivariat dengan uji chi square, dan multivariat menggunakan uji regresi logistik. Hasil penelitian 51,4\% perawat pelaksana menyatakan ketidakpuasan kerja. Uji chi square didapatkan ada hubungan bermakna antara insentif, kesempatan promosi, dan supervisi dengan kepuasan kerja. Tidak ada hubungan antara kepemimpinan, dan kondisi lingkungan kerja dengan kepuasan kerja. Hasil uji multivariat didapatkan variabel insentif merupakan faktor dominan berhubungan dengan kepuasan kerja perawat. Diharapkan pemangku manajemen rumah sakit mempertimbangkan sistem pemberian insentif dengan memperhatikan beban dan resiko kerja berdasarkan penilaian kinerja yang objektif, mengatur sistem penjenjangan karir perawat berdasarkan prestasi kerja. Menjalankan sistem pengawasan terhadap asuhan keperawatan yang diberikan perawat pelaksana, dan segera melakukan akreditasi rumah sakit untuk meningkatkan mutu pelayanan rumah sakit.
\end{abstract}

Kata Kunci : faktor determinan, kepuasan kerja, perawat pelaksana 


\section{PENDAHULUAN}

Tenaga keperawatan merupakan pelaksana pemberi proses keperawatan di rumah sakit yang memiliki waktu terbanyak dan terlama dengan pasien dalam menjalankan aktivitasnya (Depkes RI, 2010). Perawat menjadi ujung tombak bagi suatu rumah sakit dalam memberikan pelayanan kesehatan kepada masyarakat. Apabila proses keperawatan yang diberikan tidak sesuai dengan standar praktek keperawatan, maka pelayanan kesehatan tidak akan berjalan dengan baik karena banyak perawat yang melaksanakan pekerjaannya tidak sesuai dengan standar asuhan keperawatan yang ada. Menurut Kurniadi (2012), salah satu faktor yang berhubungan dengan kurang baiknya pemberian asuhan keperawatan adalah faktor kepuasan kerja.

Kepuasan kerja (job satisfaction) merupakan gambaran keadaan emosional yang menyenangkan atau tidak menyenangkan dimana karyawan memandang pekerjaanya. Kepuasan kerja pada tingkat tertentu dapat mencegah karyawan untuk mencari pekerjaan ditempat lain (Handoko, 2010). Karyawan yang memperoleh kepuasan dari perusahaannya akan memiliki rasa keterikatan atau komitmen lebih besar terhadap perusahaan dibanding karyawan yang tidak puas. Oleh karena itu untuk menciptakan keadaan yang bernilai positif dalam lingkungan kerja, kualitas pelayanan tidak hanya tergantung dari personel keperawatan saja tetapi juga tergantung dari dukungan pihak manajerial melalui fungsi manajemennya mulai dari perencanaan, pengorganisasian, pengarahan, dan pengawasan, sehingga mampu menciptakan organisasi yang memungkinkan pekerja tumbuh, meningkatkan motivasi dan produktivitas, menunjukkan penghargaan yang positif terhadap pekerja, mengakui prestasi serta mendorong tercapainya kepuasan kerja.

Kepuasan kerja menjadi masalah yang cukup menarik dan penting untuk diselidiki karena terbukti besar manfaatnya baik bagi kepentingan pegawai, perusahaan atau organisasi dan masyarakat. Rumah Sakit Umum Daerah (RSUD) Dr. Rasidin Padang merupakan salah satu rumah sakit rujukan dari puskesmas-puskesmas yang ada di kota Padang dengan kapasitas tempat tidur sebanyak 146 tempat tidur. RSUD Dr. Rasidin Padang memiliki tenaga perawat sebanyak 82 orang yang mencakup tenaga PNS maupun non PNS dengan strata pendidikan 19 orang tamatan S1 keperawatan (Ners), 55 orang tamatan D III keperawatan dan 3 orang D III perawat gigi, masih adanya perawat dengan pendidikan SPK sebanyak 5 orang.

Laporan tahunan RSUD dr. Rasidin yang didapatkan dari Rekam Medik berdasarkan tingkat pemanfaatan tempat tidur adalah: Bed Occupancy Rate (BOR) mengalami penurunan sebesar $2,28 \%$ yaitu dari $28,48 \%$ menjadi $26,20 \%$ (standar 60 $85 \%$ ), ini berarti kepercayaan masyarakat terhadap pelayanan RSUD semakin menurun. Turn Over Interval (TOI) tidak sesuai yaitu selama 11,37 hari (standar 1-3 hari), menandakan jarak kekosongan tempat tidur terisi kembali sangat lama. Bed Turn Over (BTO) masih kurang dari standar yaitu 23,30 kali (standar 40-50 kali).

Berdasarkan data tersebut, terlihat mutu pelayanan keperawatan belum baik yang menyebabkan ketidakpuasan pasien dan keluarga sebagai penerima pelayanan mengakibatkan banyak pasien memilih pindah ke rumah sakit lain. Ketidak puasan pasien dan keluarga ini bisa disebabkan oleh hasil pencapaian kinerja perawat yang rendah. Kinerja perawat yang belum optimal ini dikarenakan ketidakpuasan perawat terhadap beberapa hal seperti insentif yang tidak memuaskan, kondisi lingkungan RSUD yang tidak memadai, seringnya terjadi banjir, ketersediaan alat yang kurang dan rusak, jarak tempuh yang jauh juga menjadi pemicu 
rendahnya minat masyarakat untuk mendapatkan pelayanan kesehatan.

Studi pendahuluan melalui penyebaran angket terhadap 25 orang perawat pelaksana tentang persepsi perawat terhadap kepuasan kerja didapatkan hasil bahwa $63 \%$ perawat belum puas terhadap pemberian insentif dari rumah sakit, $56,6 \%$ perawat menyatakan kesempatan promosi seperti sistem penjenjangan karir, melanjutkan pendidikan, dan mengikuti pelatihan belum jelas dan tidak berjalan dengan baik. $50 \%$ perawat pelaksana mengatakan kondisi lingkungan kerja tidak mendukung, seringnya banjir dan banyak peralatan yang rusak. $60 \%$ kepemimpinan manajerial kurang berjalan dengan baik seperti SOP belum sepenuhnya dijalankan. $65 \%$ perawat menyatakan supervisi jarang dilakukan. Jika dirujuk pada standar Depkes, kepuasan kerja perawat lebih dari $90 \%$, hal ini menggambarkan masih belum tercapainya kepuasan kerja perawat.

Berdasarkan permasalahan tersebut maka rumusan masalah penelitian apa sajakah faktor determinan yang berhubungan dengan kepuasan kerja perawat pelaksana dengan tujuan penelitian untuk mengetahui faktor determinan yang berhubungan dengan kepuasan kerja perawat pelaksana di RSUD dr. Rasidin Padang.

\section{METODE PENELITIAN}

Penelitian ini merupakan penelitian kuantitatif menggunakan metode deskriptif korelasional dengan pendekatan crossectional study yaitu untuk menguji adanya hubungan antara dua variabel atau lebih dan tidak dilakukan manipulasi pada variabel tersebut (Polit \& Beck, 2010). Variabel pada penelitian ini terdiri dari kepemimpinan, insentif, kondisi lingkungan kerja, promosi, supervisi, dan kepuasan kerja. Populasi dalam penelitian ini seluruh perawat pelaksana di ruang rawat inap dan rawat jalan RSUD dr. Rasidin Padang yaitu
Penyakit Dalam, Bedah, Anak, ICU, Poliklinik, dan IGD. Jumlah seluruh perawat pelaksana yaitu sebanyak 82 .

HASIL DAN PEMBAHASAN

A. Gambara Karakteristik Responden

Tabel 1. Distribusi Frekuensi Perawat

Pelaksana Berdasarkan Karakteristik

Di RSUD dr. Rasidin Padang

\begin{tabular}{lcc}
\hline \multicolumn{1}{c}{$\begin{array}{c}\text { Karakteristik Perawat } \\
\text { Pelaksana }\end{array}$} & f & \% \\
\hline Umur & & \\
>35 tahun (Dewasa Muda) & 43 & 59,7 \\
$>$ 35 tahun (Dewasa Tua) & 29 & 40,3 \\
Jenis Kelamin & & \\
Laki-laki & 2 & 2,8 \\
Perempuan & 70 & 97,2 \\
Pendidikan & & \\
D III Keperawatan & 46 & 63,9 \\
S1/Ners & 26 & 36,1 \\
Masa Kerja & & \\
<5 tahun (Baru) & 17 & 23,6 \\
$>5$ tahun (Lama) & 55 & 76,4 \\
Status Kepegawaian & & \\
PNS & 68 & 94,4 \\
Non PNS & 4 & 5,6 \\
\hline
\end{tabular}

Lebih dari separuh $(59,7 \%)$ perawat pelaksana berada pada usia $\leq 35$ tahun (dewasa muda), umumnya $(97,2 \%)$ perawat pelaksana dengan jenis kelamin perempuan, lebih dari separuh $(63,9 \%)$ pendidikan perawat pelaksana DIII Keperawatan, sebagian besar $(76,4 \%)$ perawat pelaksana dengan masa kerja > 5 tahun, dan pada umumnya $(94,4 \%)$ status pegawai perawat pelaksana PNS.

\section{B. Kepuasan Kerja Perawat Pelaksana Tabel 2. Distribusi Frekuensi Perawat Pelaksana Berdasarkan Kepuasan Kerja Di RSUD dr. Rasidin Padang}

\begin{tabular}{ccc}
\hline Kepuasan Kerja & F & \% \\
\hline Puas & 35 & 48,6 \\
Tidak Puas & 37 & 51,4 \\
\hline \multicolumn{2}{c}{ Persentase } & perawat pelaksana yang
\end{tabular}
menyatakan tidak puas lebih banyak yaitu $51,4 \%$ dari pada yang merasakan puas sebesar $48,6 \%$. Dilihat dari nilai kepuasan kerja rata-rata adalah $(39,31)$. 
Jika dirujuk pada standar Depkes, kepuasan kerja perawat lebih dari $90 \%$. Maka dengan ini kepuasan kerja perawat pelaksana di RSUD dr. Rasidin Padang sangat rendah. Perawat pelaksana yang tidak puas dalam bekerja di disebabkan karena tidak puas terhadap kebijakan sistem penjenjangan karir $(73,26 \%)$, tidak puas dengan pembagian insentif yang diterima $(51,05 \%)$, tidak adanya sistem yang jelas dalam perencanaan kepegawaian rumah sakit $(69,44 \%)$, tidak puas dengan ketersediaan alat untuk melaksanakan asuhan keperawatan $(60,06 \%)$, tidak puas dengan kesempatan untuk promosi jabatan $(63,54 \%)$, tidak puas dengan sistem pengawasan pihak manajerial $(70,48 \%)$, tidak puas karena tidak adanya feedback supervisi yang dilakukan manajerial $(67,36 \%)$.

\section{Faktor Determinan Perawat Pelaksana}

\begin{tabular}{|c|c|c|}
\hline Pelaksana & Berdasarkan & Faktor \\
\hline $\begin{array}{l}\text { Determinan } \\
\text { Padang }\end{array}$ & RSUD & Rasidin \\
\hline
\end{tabular}

\begin{tabular}{lcc}
\hline \multicolumn{1}{c}{ Faktor Determinan } & F & \% \\
\hline Kepemimpinan & 38 & 52,8 \\
Baik & 34 & 47,2 \\
Kurang Baik & & \\
Insentif & 36 & 50 \\
Baik & 36 & 50 \\
Kurang Baik & & \\
Kondisi Ling. Kerja Baik & 30 & 41,7 \\
Kurang Baik & 42 & 58,3 \\
& & \\
Kesempatan Promosi & 29 & 40,3 \\
Baik & 43 & 59,7 \\
Kurang Baik & & \\
Supervisi & 38 & 52,8 \\
Baik & 34 & 47,2 \\
\hline
\end{tabular}

kepemimpinan manajerial baik, persentase insentif yang didapatkan antara yang baik dan yang kurang baik sebanding (50\%), lebih dari separuh (58,3\%) kondisi lingkungan kerja kurang baik, lebih dari separuh $(59,7 \%)$ perawat pelaksana menyatakan kesempatan promosi kurang baik, dan lebih dari separuh $(52,8 \%)$ supervisi baik di RSUD dr. Rasidin Padang.

D. Hubungan Faktor Determinan Dengan Kepuasan Kerja Perawat Pelaksana

\section{Hubungan Kepemimpinan Manajerial Dengan Kepuasan Kerja Perawat Pelaksana}

Proporsi perawat pelaksana dengan persepsi kepemimpinan manajerial baik menghasilkan kepuasan kerja yang puas sebesar $50 \%$ dibandingkan dengan kepemimpinan manajerial kurang baik yaitu $47,1 \%$. Perawat pelaksana yang menyatakan puas terhadap kepemimpinan manajernya disebabkan karena merasa pemimpinnya sudah mempunyai kejelasan sistem kerja dan telah mensosialisasikan nya $(64,23 \%)$, puas karena pimpinan sudah berlaku adil terhadap pembagian kerja bedasarkan kemampuan yang dimiliki perawat $(62,15 \%), \quad$ manajemen keperawatan telah memotivasi perawat dalam bekerja (62,5\%), karu mempertimbangkan ide dan saran perawat dalam pengambilan keputusan di ruangan $(56,94 \%)$, pemimpin bersikap terbuka dalam setiap pengambilan keputusan $(63,54 \%)$, dan karu mendelegasikan tugas secara penuh kepada perawat di ruangan $(63,54 \%)$.

2. Hubungan Insentif Dengan Kepuasan Kerja Perawat Pelaksana

Proporsi perawat pelaksana dengan persepsi insentif baik menghasilkan kepuasan kerja yang puas sebesar $75 \%$ dibandingkan dengan insentif kurang baik yaitu $22,2 \%$. Perbedaan ini bermakna secara statistik dengan nilai $\mathrm{p}=0,0001(\alpha$ $=0,05)$, maka dapat disimpulkan ada hubungan yang bermakna antara insentif dengan kepuasan kerja perawat pelaksana di RSUD dr. Rasidin Padang 
Tabel 4. Hubungan Faktor Determinan Dengan Kepuasan Kerja Perawat Pelaksana di RSUD dr. Rasidin Padang

\begin{tabular}{|c|c|c|c|c|c|c|c|c|c|}
\hline \multirow{3}{*}{\multicolumn{2}{|c|}{ Faktor Determinan }} & \multicolumn{4}{|c|}{ Kepuasan Kerja } & \multirow{2}{*}{\multicolumn{2}{|c|}{ Total }} & \multirow{3}{*}{ Nilai $p$} & \multirow{3}{*}{$\begin{array}{c}\text { OR } \\
(\mathrm{CI} 95 \%)\end{array}$} \\
\hline & & \multicolumn{2}{|c|}{ Puas } & \multicolumn{2}{|c|}{ Tidak Puas } & & & & \\
\hline & & $\mathrm{f}$ & $\%$ & $\mathrm{f}$ & $\%$ & $\mathrm{f}$ & $\%$ & & \\
\hline \multirow[t]{4}{*}{1.} & Kepemimpinan & & & & & & & & \\
\hline & Manajerial & & & & & & & \multirow{3}{*}{0,990} & \\
\hline & Baik & 19 & 50,0 & 19 & 50,0 & 38 & 100 & & - \\
\hline & Kurang Baik & 16 & 47,1 & 18 & 52,9 & 34 & 100 & & \\
\hline \multirow[t]{3}{*}{2.} & Insentif & & & & & & & \multirow{3}{*}{0,0001} & 10,500 \\
\hline & Baik & 27 & 75,0 & 9 & 25,0 & 36 & 100 & & $(3,533-$ \\
\hline & Kurang Baik & 8 & 22,2 & 28 & 77,8 & 36 & 100 & & $31,207)$ \\
\hline \multirow[t]{3}{*}{3.} & Kondisi Lingkungan Kerja & & & & & & & \multirow{3}{*}{0,359} & \\
\hline & Baik & 17 & 56,7 & 13 & 43,3 & 30 & 100 & & - \\
\hline & Kurang Baik & 18 & 42,9 & 24 & 57,1 & 42 & 100 & & \\
\hline \multirow[t]{3}{*}{4.} & Kesempatan Promosi & & & & & & & \multirow{3}{*}{0,034} & 3,206 \\
\hline & Baik & 19 & 65,5 & 10 & 34,5 & 29 & 100 & & $(1,198-$ \\
\hline & Kurang Baik & 16 & 37,2 & 27 & 62,8 & 43 & 100 & & $8,579)$ \\
\hline \multirow[t]{3}{*}{5.} & Supervisi & & & & & & & \multirow{3}{*}{0,001} & 6,019 \\
\hline & Baik & 26 & 68,4 & 12 & 31,6 & 38 & 100 & & $(2,162-$ \\
\hline & Kurang Baik & 9 & 26,5 & 25 & 73,5 & 34 & 100 & & $16,756)$ \\
\hline
\end{tabular}

Perawat pelaksana yang menyatakan insentif baik dan puas bekerja disebabkan karena insentif yang diberikan sesuai dengan tingkat pendidikan $(74,30 \%)$, insentif yang diberikan mendorong semangat kerja $(63,88 \%)$, pembagian insentif berdasarkan penilaian kinerja yang objektif $(62,5 \%)$, insentif yang diterima sesuai dengan profesi $(57,98 \%)$, puas terhadap sistem remunerasi yang telah disosialisasikan $(54,16 \%)$, pembagian insentif sudah sesuai dengan yang diharapkan $(53,12 \%)$.

\section{Hubungan Kondisi Lingkungan Kerja Dengan Kepuasan Kerja Perawat Pelaksana}

Proporsi perawat pelaksana dengan persepsi kondisi lingkungan kerja baik menghasilkan kepuasan kerja yang puas sebesar $56,7 \%$ dibandingkan dengan kondisi lingkungan kerja kurang baik yaitu 42,9\%. Perbedaan ini tidak bermakna secara statistik dengan nilai $\mathrm{p}=$ $0,359(\alpha=0,05)$, maka dapat disimpulkan tidak ada hubungan yang bermakna antara kepemimpinan manajerial dengan kepuasan kerja perawat pelaksana di RSUD dr. Rasidin Padang.

$$
\text { Perawat pelaksana yang }
$$

menyatakan kondisi lingkungan kerja baik dan puas bekerja disebabkan karena perawat pelaksana merasa sentuhan perhatian manajerial keperawatan membuat suasana kerja menyenangkan (75,69\%), peralatan yang tersedia selalu dalam keadaan baik untuk digunakan $(64,93 \%)$, alat kesehatan yang ada telah mengikuti perkembangan teknologi $(74,65 \%)$, dan disiplin rekan kerja memberikan kenyamanan perawat dalam menjalankan tugas $(81,59 \%)$.

Sedangkan perawat yang merasakan ketidak puasan disebabkan karena perawat merasa lingkungan rumah sakit dan ruangan tidak bersih sehingga membuat perawat dalam melaksanakan tugas tidak nyaman $(83,68 \%)$, rumah sakit tidak memiliki panduan keselamatan kerja bagi perawat $(83,33 \%)$, SPO dalam melaksanakan tindakan keperawatan belum memperhatikan keamanan kerja perawat $(77,77 \%)$, dan perawat merasa pihak manajemen rumah sakit belum mensosialisasikan tentang petunjuk keselamatan kerja $(79,86 \%)$. 


\section{Hubungan Kesempatan Promosi} Dengan Kepuasan Kerja Perawat Pelaksana

Proporsi perawat pelaksana dengan persepsi kesempatan promosi baik menghasilkan kepuasan kerja yang puas sebesar $65,5 \%$ dibandingkan dengan kesempatan promosi kurang baik yaitu $37,2 \%$. Perbedaan ini bermakna secara statistik dengan nilai $\mathrm{p}=0,034(\alpha=0,05)$, maka dapat disimpulkan ada hubungan yang bermakna antara kondisi lingkungan kerja dengan kepuasan kerja perawat pelaksana di RSUD dr. Rasidin Padang.

Perawat pelaksana yang menyatakan kesempatan promosi baik dan kepuasan bekerja disebabkan oleh perawat mempunyai kesempatan untuk melanjutkan kependidikan $\quad(72,22 \%), \quad$ adanya kesempatan naik pangkat bagi perawat yang rajin $(60,76 \%)$, setiap perawat mempunyai kesempatan yang sama untuk mengikuti pelatihan $(60,06 \%)$, sudah adanya perencanaan dalam pengembangan karyawan $(61,11 \%)$, adanya kejelasan sistem pengembangan pendidikan $(59,72 \%)$. Namun untuk penjenjangan karir keperawatan masih berdasarkan senioritas $(58,33 \%)$, dan tidak semua perawat yang berprestasi mendapatkan kesempatan promosi jabatan $(56,25 \%)$.

\section{Hubungan Supervisi Dengan Kepuasan Kerja Perawat Pelaksana}

Proporsi perawat pelaksana dengan persepsi supervisi baik menghasilkan kepuasan kerja yang puas sebesar $68,4 \%$ dibandingkan dengan persepsi supervisi kurang baik yaitu 26,5\%. Perbedaan ini bermakna secara statistik dengan nilai $\mathrm{p}=$ $0,001(\alpha=0,05)$, maka dapat disimpulkan ada hubungan yang bermakna antara supervisi dengan kepuasan kerja perawat pelaksana di RSUD dr. Rasidin Padang. Dalam penelitian ini perawat pelaksana yang menyatakan supervisi baik dan puas bekerja disebabkan karena bidang keperawatan sudah menentukan target standar pelaksanaan program asuhan keperawatan $(62,84 \%)$, sudah adanya sistem operasional prosedur $(66,66 \%)$, manajemen keperawatan sudah mengembangkan peraturan dan perbaikan standar operasional $(66,66 \%)$, atasan memberikan bimbingan pada bawahan setiap ada kesulitan dalam melakukan asuhan keperawatan $(65,97 \%)$, kemajuan kualitas pelayanan pada pasien $(67,70 \%)$, supervisi yang dilakukan bermanfaat untuk kepuasan pasien $(69,44 \%)$.

Perawat pelaksana yang menyatakan supervisi baik dan puas bekerja disebabkan karena bidang keperawatan sudah menentukan target standar pelaksanaan program asuhan keperawatan $(62,84 \%)$, sudah adanya sistem operasional prosedur $(66,66 \%)$, manajemen keperawatan sudah mengembangkan peraturan dan perbaikan standar operasional $(66,66 \%)$, atasan memberikan bimbingan pada bawahan setiap ada kesulitan dalam melakukan asuhan keperawatan $(65,97 \%)$, kemajuan kualitas pelayanan pada pasien $(67,70 \%)$, supervisi yang dilakukan bermanfaat untuk kepuasan pasien $(69,44 \%)$.

\section{Variabel Yang Paling Berhubungan Dengan Kepuasan Kerja Perawat Pelaksana}

Variabel yang memiliki hubungan paling dominan dengan kepuasan kerja perawat pelaksana adalah variabel insentif yang memiliki nilai $\mathrm{p}$ terkecil (nilai $\mathrm{p}=$ $0,0001)$ dan nilai $\mathrm{OR}$ terbesar $(\mathrm{OR}=$ $8,217)$. Hal ini menandakan kekuatan hubungan variabel insentif adalah 8, 217 kali menyebabkan perawat pelaksana merasakan kepuasan dalam bekerja.

Menurut Moekijad (2005), upah yang diterima oleh pegawai harus mudah dipahami dan tepat waktu. Upah yang terlambat diberikan mengakibatkan kemarahan dan rasa tidak puas pegawai yang pada gilirannya akan dapat mengurangi produktivitas pekerja. Adanya insentif di ruangan merupakan tambahan penghasilan yang sangat diharapkan oleh perawat yang akan meringankan biaya 
hidup yang semakin meningkat pada saat sekarang ini. Demikian juga dengan pembagian insentif yang tepat waktu, perawat akan merasa senang karena usahanya dihargai sehingga kepuasan kerja perawat pelaksanan akan meningkat.

\section{KESIMPULAN}

Berdasarkan hasil penelitian yang dilakukan pada 72 orang perawat pelaksana di RSUD dr. Rasidin Padang dapat disimpulkan : Lebih dari separuh $(51,4 \%)$ perawat pelaksana menyatakan ketidak puasan kerja, lebih dari separuh $(52,8 \%)$ perawat pelaksana menyatakan kepemimpinan manajerial baik, perawat pelaksana menyatakan insentif yang didapatkan antara baik dengan kurang baik sebanding (50\%), lebih dari separuh perawat $(58,3 \%)$ pelaksana menyatakan kondisi lingkungan kerja kurang baik, lebih dari separuh $(59,7 \%)$ perawat pelaksana menyatakan kesempatan promosi kurang baik, lebih dari separuh $(52,8 \%)$ perawat pelaksana menyatakan supervisi yang dilakukan baik, tidak ada hubungan yang bermakna antara kepemimpinan manajerial dengan kepuasan kerja perawat pelaksana, ada hubungan yang bermakna antara insentif dengan kepuasan kerja perawat pelaksana, tidak ada hubungan yang bermakna antara kondisi lingkungan kerja dengan kepuasan kerja perawat pelaksana, ada hubungan yang bermakna antara kesempatan promosi dengan kepuasan kerja perawat pelaksana, ada hubungan yang bermakna antara supervisi dengan kepuasan kerja perawat pelaksana, variabel yang paling dominan berhubungan dengan kepuasan kerja perawat pelaksana adalah insentif dengan nilai $\mathrm{p}=0,0001$ dan nilai $\mathrm{OR}$ sebesar 8,217, yang artinya insentif mempunyai kekuatan 8,217 kali menyebabkan kepuasan kerja perawat pelaksana.

Manajemen Rumah Sakit diharapkan mempertimbangkan sistem pemberian insentif dengan memperhatikan beban kerja dan resiko kerja berdasarkan penilaian kinerja yang objektif, sehingga insentif yang didapatkan sebagai salah satu reward yang dapat memuaskan perawat, melakukan upaya untuk meningkatkan kepuasan kerja dengan cara memberikan kesempatan kenaikan jabatan sebagai penjenjangan karir dan kenaikan pangkat perawat sesuai dengan latar belakang pendidikan yang dimiliki dan prestasi kerja dan memperbaiki dan menjalankan sistem pengawasan terhadap asuhan keperawatan yang diberikan perawat pelaksana kepada pasien dan keluarga sehingga dapat memperbaiki kekurangan-kekurangan yang ada serta meningkatkan pelayanan yang bermutu.

\section{DAFTAR PUSTAKA}

Anwar, K. (2013). Manajemen Keperawatan dan Prosfektifnya (Teori, Konsep dan Aplikasi). Jakarta: FK UI.

Bateman, dan Snell. (2002). Manajemen Kepemimpinan dan Kolaborasi dalam Dunia Pendidikan yang Kompetitif. Jakarta: Salemba Empat.

Burns, N. and Grove, S.K. (2008). The Practice of Nursing Research: Apraisal, Synthesis and Generation of Evidance, 6 th. End, St. Louis: Saunders-Elsevier.

Bustami. (2011). Penjaminan Mutu Pelayanan Kesehatan. Jakarta: Erlangga.

Davis, K \& Neestrom, J.W. (2004). Perilaku Dalam Organisasi. Jakarta: Erlangga.

Departemen Kesehatan RI. (2006). Penataan Sistem Jenjang Karir Perawat. Jakarta.

Endah, Setyowati. (2003). Pengembangan SDM Berbasis Kompetensi; Solusi Untuk Meningkatkan Kinerja Organisasi. Jurnal Administrasi Publik FIA. Malang: Universitas Brawijaya.

Flippo, Erwin (2000). Manajemen Personalia, Terjemahan (Moh. Masud). Cetakan Kedelapan. Jakarta: Erlangga. 
Gibson, J. L, Ivance, J.M \& Donelly, J.H. (2009). Organisasi: Perilaku, Struktur dan Proses. (Alih Bahasa: N. Ardiani), Jilid I, Edisi 8. Jakarta: Binarupa Aksara.

Gillies.D.A. (1996). Nursing Management System Aprroach. Philadhelpia: W.B. Saunders Company.

Gomes, F.C. (2003). Manajemen Sumber Daya Manusia ; Edisi II. Yogyakarta: Andi Ofset.

Hasibuan, Malayu, SP. (2003). Manajemen Sumber Daya Manusia. Jakarta: PT. Bumi Aksara.

Hubberd, D. (2000). Leadership Nursing Care Management. Second Edition. Philadelphia: W.B. Saunders Company.

Ilyas, Y. (2001). Perencanaan SDM Rumah Sakit. Teori, Metoda dan Formula. Edisi Revisi. Jakarta: Pusat Kajian Ekonomi Kesehatan FKM UI.

Irawan,U. (2002). 10 Prinsip Kepuasan Pelanggan. Jakarta: PT Elek Media Komputindo.

Komisi Akreditasi Rumah Sakit. (2013). Pedoman Tata Laksana Supervisi Akreditasi Rumah Sakit, Edisi II. Jakarta.

Kuswandi, (2004). Cara Mengukur Kepuasan Kerja. Jakarta: PT. Elex Media Komputindo.

Marquis \& Huston. (2003). Kepemimpinan dan Manajemen Keperawatan; Teori dan Aplikasi. Jakarta: EGC.

Moekijat. (2005). Administrasi Gaji dan Upah. Bandung: Pertama Mandar Maju.

Noe, R, dkk. (2011). Manajemen Sumber Daya Manusia. Jakarta: Salemba Empat.

Notoatmodjo, S. (2010). Promosi Kesehatan dan Ilmu Perilaku. Jakarta: Rineka Cipta.

Nursalam. (2011). Manajemen Keperawatan : Aplikasi dalam Praktek Keperawatan Profesional. Edisi 2. Jakarta: Salemba Medika.

Polit, D.F \& Back, C.T. (2010). Essentials of Nursing Research; Methods, Appraisal \& Utilization. Philadelphia: Lippincott Williams \& Wilkins.

Robbins, Stephan P. \& Judge, Timothy A. (2008). Perilaku Organisasi; Organizasional Behaviour. Buku 1. Edisi 12. Jakarta: Salemba Empat.

Sarwono, Sarlito Wirawan. (2005). Psikologi Lingkungan. Jakarta: PT. Gramedia Grasindo.

Siagian.S.P. (2000). Fungsi-fungsi Manajemen. Jakarta: Bumi Aksara.

Siswanto, SB. (2003). Manajemen Tenaga Kerja Indonesia. Jakarta: Bumi Aksara.

Sugiyono. (2010). Metode Penelitian Kuantitatif, dan $R \& D$. Bandung: Alfabet.

Suroso, J (2011). Laporan Tesis. Penataan Jenjang Karir Untuk Meningkatkan Kompetensi Kepuasan Kerja dan Kinerja Perawat Pelaksana di RSUD Banyumas Tahun 2011.

Suyanto. (2009). Mengenal Kepemimpinan dan Manajemen Keperawatan di Rumah Sakit. Yogyakarta: Mitra Cendekia Press.

Swansburg, RC. (1999). Introductory Manajement and Leadership for Nurse. $2^{\text {nd }}$ Edition.Toronto: Jonash and Burtlet Publisher.

Wibowo. (2011). Manajemen Kinerja. Jakarta: Rajawali Pers. 